\title{
A Visual Pattern of Two Decades of Literature on Mobile Learning: A Bibliometric Analysis
}

\author{
Siti Zuraidah Md Osman* \\ Universiti Sains Malaysia, Penang, Malaysia \\ https://orcid.org/0000-0003-0627-9543 \\ Ro'azeah Md Napeah \\ Universiti Sains Malaysia, Penang, Malaysia \\ https://orcid.org/0000-0003-2299-9719
}

\begin{abstract}
Mobile learning, or m-Learning, has grown in popularity significantly over the last few decades, as evidence of educators and students worldwide using the device as a teaching and learning tool continues to accumulate. The pattern of mobile-learning research from 2001 to 2020 is determined by bibliometric analysis. The study retrieved 3,874 documents for further analysis, based on the keywords associated with mobile learning in the article's title. The maps depicted the connections between the researchers, countries, all keywords, titles, and abstracts. The title and abstract of this study are used to visualise the cooccurring terms of various phases or concepts associated with mobile learning that were extracted from the Scopus database. The findings indicate strong and direct connections between the concepts in e-learning, implying a significant and direct research connection. China was the leading country in mobile-learning research, and the leading journal was Computers and Education. The top author's keywords in terms of cooccurrence were "mobile learning", "e-learning", "students", "learning systems", and "m-learning". To conduct a two-decade analysis, this study excludes any publications from the years 1984 and 2021. These critical analyses of prior work are valuable and indispensable resources for mobile-learning scholars and practitioners. It is believed that onlinelearning applications have increased students' engagement; and it has eliminated the accessibility gap. Consequently, mobile learning is expected to maintain its popularity over the next few decades.
\end{abstract}

Keywords: mobile learning; m-learning; Scopus; bibliometric analysis; VOS-viewer

\footnotetext{
*Corresponding author: Siti Zuraidah Md Osman, sitizuraidah@usm.my
} 


\section{Introduction}

Mobile learning, also known as m-learning, is growing in popularity, as technology and multimedia advance. Prillya et al. (2021) define mobile learning as a technology that can be used to acquire knowledge from anywhere; and it can give complete support in attaining effective learning and early appearance, as well as an assessment-based initial appearance. Mobile learning has increased in popularity recently, due to the ease with which the internet can now be accessed (Díaz-Sainz et al., 2021; Goksu, 2021). It connects the data (Sungur-gul, 2021); and it facilitates learning in various fields (Barrett et al., 2021; Díaz-Sainz et al., 2021). According to Huang et al. (2021), mobile learning is defined as learning that occurs on mobile devices that can be accessed at any time, and from any location (Akour et al., 2021; Mutiaraningrum \& Nugroho, 2021).

Simultaneously, mobile applications serve as mobile-learning devices (Goksu, 2021). Today, a variety of mobile devices are available, including smartphones, laptops and tablets. As a result of contemporary technological advances, learners now have access to affordable, more convenient, new, accessible, portable, and digital technology (Criollo-C, Guerrero-Arias et al., 2021). Students can create, own, transform, discuss, discard, share, store and disseminate ideas, opinions, images and information through mobile learning, thereby transforming their identities and communities. Due to their portability and ubiquity, mobile devices have become indispensable in our daily lives, and particularly in the educational sector (Akour et al., 2021; Díaz-Sainz et al., 2021; Sungur-gul, 2021).

Mobile technology has the potential to shift the educational paradigm away from imposed instruction and towards cooperative learning (Criollo-C, Moscoso-Zea et al., 2021). As a result, mobile devices and their capabilities revolutionise and enhance current educational practices (Criollo-C, Guerrero-Arias et al., 2021; Har et al., 2019).

The usage and effects of mobile learning have been extensively addressed, by researchers in the educational theoretical aspect, such as in a technologyacceptance model and in a mobile-technology acceptance model (Moya \& Camacho, 2021; Yuan, et al., 2021). The question arises about pedagogy that has stood out in digital literacy, while the technological resources category has had the least-relevant assessment by researchers (Moya \& Camacho, 2021). Indeed, interactions seem to be a major challenge experienced by students ; since they hinder the effectiveness of mobile learning (Yuan et al., 2021).

Consequently, practitioners and researchers need to have a clearer definition and a better description of the idea, allowing them to design a learning experience that is supported by more effective and flexible mobile technology (Viberg et al., 2021). Thus, these issues require looking at the pattern of co-occurrence analysis over these two decades, which has addressed the most frequently discussed mobilelearning topics among academics and the areas of mobile learning that require additional research. 
Therefore, this study was conducted by using Microsoft Excel, Harzing's Publish or Perish, and VOS-viewer software, in order to analyse the data and the visualisation of the research-publication pattern on mobile learning. The evolutionary analysis and the co-occurrence analysis through VOS-Viewer, a software tool for creating and visualising bibliometric networks, was used to explore the evolutionary process of mobile-learning research, and to predict the future developmental trends.

\section{The Literature Review}

Nowadays, mobile-device learning is integrated into almost all knowledgerelated activities in the classroom (Díaz-Sainz et al., 2021; Nurul \& Nailul, 2018). As today's young learners, dubbed digital natives, have developed technical skills that enable them to succeed through mobile-device learning, they are constantly drawn to cutting-edge technologies, having grown up with internet access, social media, and mobile devices. As a result, mobile learning has emerged, as being the primary strategy for educational innovation, rapidly growing in popularity and resulting in widespread educational innovation (Criollo-C, Guerrero-Arias et al., 2021; Díaz-Sainz et al., 2021).

With mobile learning's continued growth, there have been attempts to compile data on the global scientific output of mobile-learning studies (Elaish et al., 2019). According to Shi et al. (2020), bibliometric analysis is a valid and potentially equitable method for quantifying a paper's contribution, in order to assist academics when studying this subject by narrowing their future research directions among the numerous current methods for analysing the literature. As a result, bibliometric analysis is frequently used to determine the patterns and impacts, including publishing countries, subject fields, journals and authors' keywords (Donthu et al., 2021).

Due to the increase in the number of studies on mobile learning, the strength of the relationship between new mobile applications and mobile-learning activities is getting stronger; it has been recognised that mobile learning is a critical and growing field for improving learning performance. Although there are many studies on mobile learning, research by using bibliometric visualisation-mapping methods in a broad context and presenting network maps in diverse variables is still ongoing, which includes the keywords of mobile learning. As such, it is critical to provide an up-to-date map, visualisation and clustering of a mobile learning publication timeline for the Scopus datasets between 2001 and 2020. The current study identifies the visualisation of mobile-learning patterns; and it makes some recommendations for the direction of future research.

As such, this study will analyse and visualise the two-decade body of literature on mobile learning from 2001 to 2020. The study's research question is, first and foremost, what is the recent publication pattern in mobile learning? Secondly, what is the current citation pattern for mobile-learning publications? Thirdly, what are the most frequently discussed mobile-learning topics among academics? Finally, what areas of mobile learning still require additional research? 


\section{The Method}

The method used in this study is based on the data gathered and filtered through to a definitive collection of reliable and suitable data for analysis. The topic and scope of the study must be determined first in the context of the purpose of the study; in this case, we want to focus on all the studies related to mobile learning and published in the Scopus database. Scopus was chosen; because it is the world's largest abstracting and indexing database, as well as one of the largest searchable databases of citations and abstracts (Ahmi \& Mohamad, 2019; Ahmi \& Mohd Nasir, 2019; Burnham, 2006). The database includes 67 million records from more than 22,500 serial titles, 96,000 conferences, and 136,000 books published by more than 7,500 different publishers worldwide (Cantu-Ortiz, 2017).

As illustrated in Figure 1, PRISMA was adopted from Moher et al. (2009), to select the documents for this study, based on the research process. The data were extracted on 4th May 2021; and the following keyword combination was used to identify all the target publications on "m-learning" or "mobile learning".

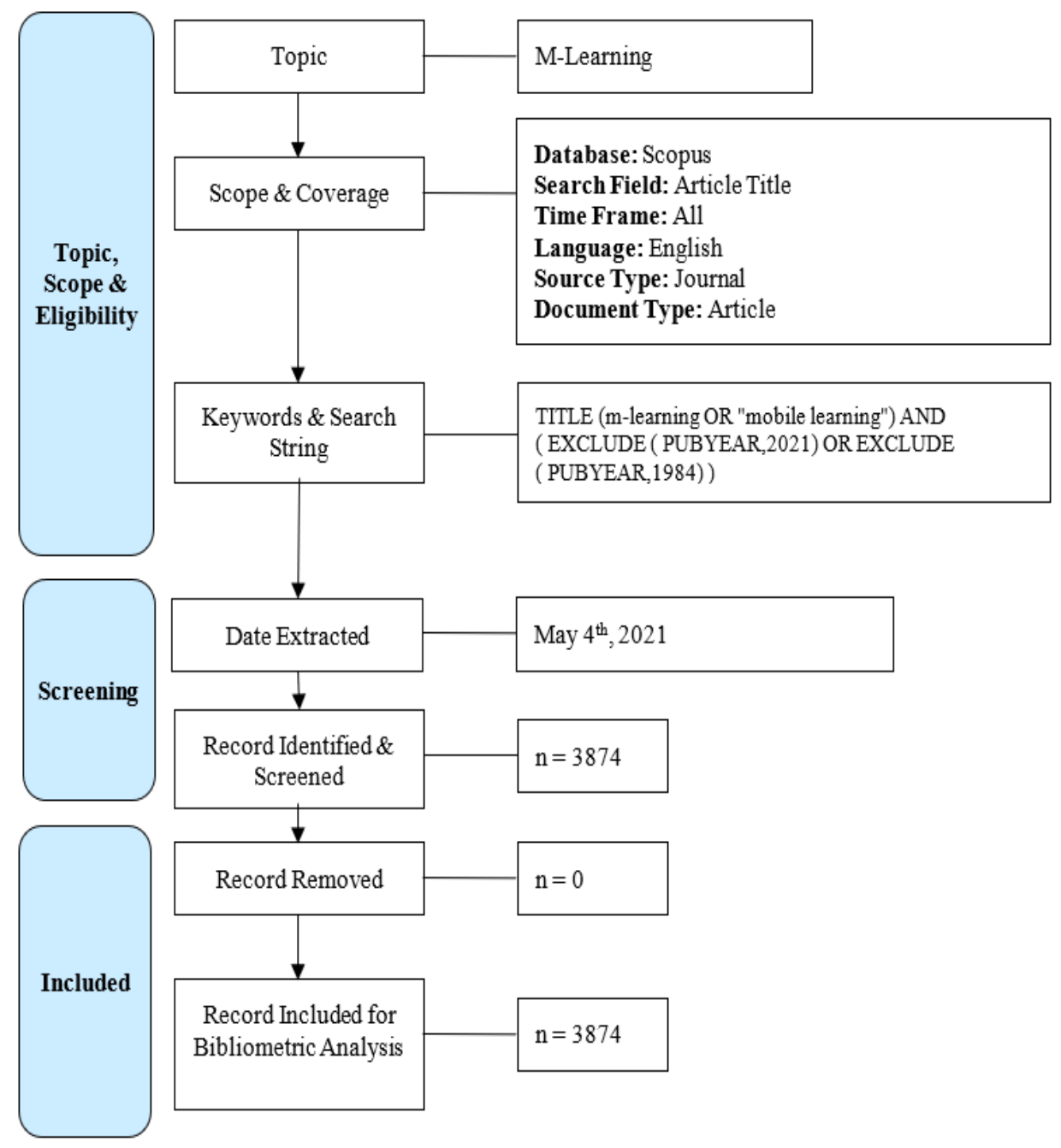

Figure 1: The research protocol 
Due to the scarcity of bibliometric studies on mobile learning, we limited our search to those documents relating to mobile learning or m-learning works. As Donthu, et al. (2021) state that the scope of bibliometric analysis is broad; and the dataset is large. TITLE (m-learning OR "mobile learning") AND (EXCLUDE (PUBYEAR, 2021) OR EXCLUDE (PUBYEAR, 1984)). This query returned 3,874 documents. A series of data-cleansing operations revealed that there were no duplicate documents. As a result, the same number of documents was retained following the process. The data were then exported as research information systems (RIS) and comma-separated values (CSV) files. The primary search-query TITLES ("m-learning" and "mobile learning" and "bibliometric analysis") were used in this study to determine how much of this field had been studied previously by using bibliometric analysis; and the query returned only one result.

The dataset contains information about publications, including their type, year, the language of publication, subject area, source title, keywords, abstract, country of origin, affiliation, citations, and authorship. We performed most of the mapping analysis in this study by using the VOS-viewer software (Ding \& Yang, 2020; Van Eck \& Waltman, 2020). Hence, the importance and power of the linkages reflected by the network's size and interconnecting interlinking lines from the cooccurrent maps.

\section{The Results}

The following aspects of scholarly works were analysed to address the research questions: document types, source types, document languages, subject area, publication by year, publication by country, publication by source title, publication by institutions, citation patterns in mobile learning, based on the keywords and titles, as well as by the citation patterns. Most of the data were in the form of frequencies and percentages. In addition, the publisher's name, the current Cite Score, the SCImago Journal Rank (SJR) 2020, and the Source Normalized Impact per Paper (SNIP) 2020 for the most active source title, as reported by Scopus, were included.

SJR quantifies the weighted citations received by the source title; whereas SNIP quantifies the number of actual citations compared to the expected number of citations for the source title's topical field (Hitchcock, 2004). The citation analysis was in the form of citation metrics, and the twenty most-cited publications.

\subsection{Recent Trends in Mobile Learning Publication}

What has been the recent pattern of mobile learning publication? We analysed the publication pattern in mobile learning by using bibliographic data to address this question. This study used the total number of publications by year, document type, publication by source title, publication by country, and the publication by subject area.

\subsubsection{Year of Publication}

Table 1 shows the yearly publications on m-learning/mobile learning in detail, such as the total number of publications (TP); the total number of cited publications (NCP); the total number of citations (TC); the average number of 
citations per publication $(\mathrm{C} / \mathrm{P})$; the average number of citations per cited publication (C/CP); the h-index (h); and the g-index (g). According to the Scopus database, there is one article from 2001 that serves as the foundation for the research on the use of mobile learning in educational settings. Abernathy (2001) wrote the first paper. Further examination of this document has revealed that it is composed of brief writings in the form of magazine articles.

Interestingly, these papers have received only one citation, indicating the establishment of a new research environment by Talent Development magazine, the pioneers of mobile-learning publications. Additionally, this article was from the training and development cluster, specifically e-learning. This cluster implies that authors/researchers/practitioners pioneered the mobile-learning movement in the e-learning genre. The term "wireless" used in this study discusses the impact of mobile learning on training and the development that utilises face-to-face and remote methods, with instructors facilitating learning via laptops.

Table 1: Year of publication

\begin{tabular}{|c|c|c|c|c|c|c|c|}
\hline Year & TP & NCP & TC & C/P & C/CP & $h$ & $g$ \\
\hline 2001 & 1 & 1 & 40 & 40 & 40 & 1 & 1 \\
\hline 2002 & 10 & 10 & 455 & 45.5 & 45.5 & 8 & 10 \\
\hline 2003 & 9 & 9 & 610 & 67.78 & 67.78 & 6 & 9 \\
\hline 2004 & 16 & 12 & 390 & 24.38 & 32.5 & 7 & 16 \\
\hline 2005 & 55 & 51 & 1360 & 24.73 & 26.67 & 15 & 36 \\
\hline 2006 & 64 & 51 & 655 & 10.23 & 12.84 & 17 & 23 \\
\hline 2007 & 121 & 87 & 2537 & 20.97 & 29.16 & 19 & 49 \\
\hline 2008 & 126 & 100 & 1936 & 15.37 & 19.36 & 21 & 42 \\
\hline 2009 & 166 & 118 & 3486 & 21 & 29.54 & 21 & 58 \\
\hline 2010 & 253 & 181 & 3822 & 15.11 & 21.12 & 29 & 57 \\
\hline 2011 & 220 & 159 & 3030 & 13.77 & 19.06 & 24 & 52 \\
\hline 2012 & 291 & 206 & 4627 & 15.9 & 22.46 & 33 & 64 \\
\hline 2013 & 249 & 188 & 2899 & 11.64 & 15.42 & 23 & 48 \\
\hline 2014 & 337 & 228 & 2796 & 8.3 & 12.26 & 27 & 46 \\
\hline 2015 & 335 & 241 & 2699 & 8.06 & 11.2 & 28 & 41 \\
\hline 2016 & 322 & 235 & 2784 & 8.65 & 11.85 & 28 & 43 \\
\hline
\end{tabular}




\begin{tabular}{|c|c|c|c|c|c|c|c|}
\hline 2017 & 314 & 235 & 1819 & 5.79 & 7.74 & 21 & 31 \\
\hline 2018 & 317 & 213 & 1833 & 5.78 & 8.61 & 18 & 33 \\
\hline 2019 & 343 & 121 & 1356 & 3.95 & 11.21 & 19 & 24 \\
\hline 2020 & 325 & 124 & 428 & 1.32 & 3.45 & 9 & 14 \\
\hline Total & 3874 & & & & & & \\
\hline
\end{tabular}

In 2002, nine proceedings and one journal article on educational research contexts were published. Sharples et al. (2002) published an article on designing and implementing a mobile-learning resource for their children aged 9-11 by using a Fujitsu Stylistic LT Pen Tablet computer, or a HandLeR prototype. The prototype produced is based on a Conversational Framework that divides the system into two modules, which encourage a deliberate cycle of action and reflection to support a variety of activities and learning abilities, rather than adapting to specific learners. The action operations allow students to share their experiences through pictures, voices and written notes, to perform experiments, and to communicate with teachers and other students. However, the description provided can enable students to manage, connect and combine the onlinelearning activities by applying current and previous knowledge.

Attewell and Gustafsson (2002), Mifsud (2002), Nyiri (2002), Seppälä and Alamäki (2002), Seppälä et al. (2002) and Uther (2002), presented their research papers at the IEEE International Workshop on Wireless and Mobile Technologies in Education, WMTE 2002. These researchers were interested in the philosophy, the fundamental principles, the perceptions, and the challenges associated with transforming formal learning into mobile learning, conducting pilot tests on the use of mobile technology in teacher-training, developing prototypes by using mobile technology, and identifying pedagogical applications that are beneficial to higher education.

The findings indicate that flexible teaching solutions that enable students to access information via a variety of devices, and which support learning in various settings are necessary to engage young adults in learning, and to assist them in developing and achieving their lifelong learning objectives. However, this depends on the extent to which current knowledge regarding usability is best applied. Thus, this indicates improvement in the research foundations on the development and use of mobile-learning tools and environments by educators in an educational system that is increasingly moving towards student-centred learning by learners at any time and from any location.

Ichinohe and Suzuki (2002) and Houser et al. (2002) have used mobile devices in language learning, such as mobile-phone websites, cell phones, and Personal Digital Assistants (PDAs), among adult learners. These studies have contributed to revolutionising and quantifying the effects of mobile learning on learning activities; and they are then incorporated into a language-learning curriculum. 
Although researchers were concerned about the future of mobile learning, the study of Lo et al. (2002) developed techniques for using multi-agent systems in mobile learning platforms, in order to enhance interaction and communication between teachers and their students. This technique allows the actual needs of each student to be determined by the instructor. In addition, the use of user-client agents can monitor students' progress in multi-agent platforms, while assisting developers in delivering international mobile-production applications. This leads to developing a mobile-learning environment into a truly dynamic and global environment. These articles frequently emphasise the flexible lesson needed, in order to accomplish the learning objectives via a wireless feature in mobile learning.

Thus, these two years of pioneering articles have established a precedent for mobile learning; and they have been cited 495 times. According to records, between 2002 and 2003, the publication grew at a relatively slow pace, reaching less than 3\% in 2013; however, in early 2004, a growth of $4.34 \%$ in the number of articles published was observed. This trend fluctuated, but there was still an average of 100, 200, and 300 publications per year. The highest number of publications occurred in 2019, with 343 documents, which comprises $93 \%$. This observation denotes the irregular and peak period of the trending practice, as exemplified by educators worldwide, who employ a mobile-learning approach, as shown in Figure 2.

This scenario was understandable when the following study was conducted, particularly in the light of those countries that were participating in this study.

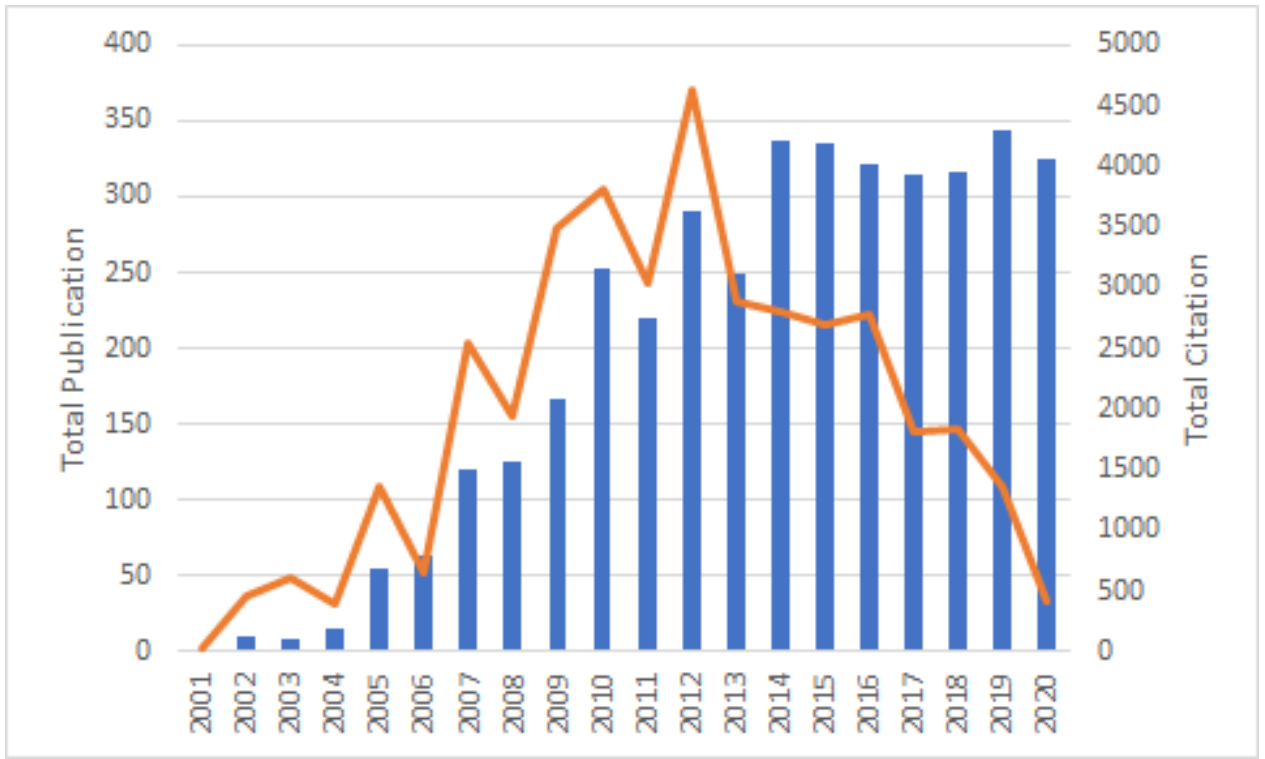

Figure 2: Total publications and citations by annal trends in mobile-learning studies

\subsubsection{Publication by Source Titles}

There is a departure from previous analyses. Elaish (2019) previously identified Educational Technology and Society as the top-ranked journal with 75 publications. According to Goksu (2021), Computer and Education ranked first with 103 
publications. Nonetheless, Table 2 indicates that the most-active source title is Lecture Notes in Computer Science, including the sub-series Lecture Notes in Artificial Intelligence and Lecture Notes in Bioinformatics, with 112 publications, followed by the International Journal of Mobile Learning and Organization (90 publications) and ACM International Conference Proceeding Series (81 publications). The Journal of Educational Technology and Society is ranked fourteenth, with 24 publications, while Computer and Education is ranked seventh, with 47 publications between 2004 and 2020. The findings indicate that mobile-learning applications are still gaining traction in the field of computer science.

Table 2: Most-active source title

\begin{tabular}{|c|c|c|c|c|c|c|c|}
\hline Source Title & $\mathbf{T P}$ & $\%$ & Publisher & $\begin{array}{l}\text { Cite } \\
\text { Score } \\
2019\end{array}$ & $\begin{array}{l}\text { Cite } \\
\text { Score } \\
2020\end{array}$ & $\begin{array}{l}\text { SJR } \\
2020\end{array}$ & $\begin{array}{l}\text { SNIP } \\
2020\end{array}$ \\
\hline $\begin{array}{l}\text { Lecture Notes in Computer } \\
\text { Science Including Sub- } \\
\text { series Lecture Notes in } \\
\text { Artificial Intelligence and } \\
\text { Lecture Notes In } \\
\text { Bioinformatics }\end{array}$ & 112 & $2.89 \%$ & Springer & 1.9 & 1.8 & 0.249 & 0.628 \\
\hline $\begin{array}{l}\text { International Journal of } \\
\text { Mobile Learning and } \\
\text { Organisation }\end{array}$ & 90 & $2.32 \%$ & Inderscience & 3.1 & 5.2 & 0.896 & 2.015 \\
\hline $\begin{array}{l}\text { ACM International } \\
\text { Conference Proceeding } \\
\text { Series }\end{array}$ & 81 & $2.09 \%$ & $\begin{array}{l}\text { Association } \\
\text { for } \\
\text { Computing } \\
\text { Machinery }\end{array}$ & $\mathrm{N} / \mathrm{A}$ & $\mathrm{N} / \mathrm{A}$ & $\mathrm{N} / \mathrm{A}$ & $\mathrm{N} / \mathrm{A}$ \\
\hline $\begin{array}{l}\text { International Journal of } \\
\text { Interactive Mobile } \\
\text { Technologies }\end{array}$ & 72 & $1.86 \%$ & $\begin{array}{l}\text { International } \\
\text { Association of } \\
\text { Online } \\
\text { Engineering }\end{array}$ & 3.1 & 2.9 & 0.316 & 1.417 \\
\hline $\begin{array}{l}\text { Communications In } \\
\text { Computer and Information } \\
\text { Science }\end{array}$ & 66 & $1.70 \%$ & Springer & 0.7 & 0.8 & 0.16 & 0.32 \\
\hline $\begin{array}{l}\text { Journal of Physics } \\
\text { Conference Series }\end{array}$ & 49 & $1.26 \%$ & $\begin{array}{l}\text { IOP } \\
\text { Publishing } \\
\text { Ltd }\end{array}$ & 0.7 & 0.7 & 0.21 & 0.464 \\
\hline Computers and Education & 47 & $1.21 \%$ & Elsevier Ltd & 13.4 & 14.4 & 3.026 & 4.411 \\
\hline $\begin{array}{l}\text { International Journal of } \\
\text { Mobile and Blended } \\
\text { Learning }\end{array}$ & 47 & $1.21 \%$ & $\begin{array}{l}\text { IGI Global } \\
\text { Publishing }\end{array}$ & 1.9 & 1.9 & 0.225 & 0.409 \\
\hline $\begin{array}{l}\text { Ceur Workshop } \\
\text { Proceedings }\end{array}$ & 45 & $1.16 \%$ & CEUR-WS.org & 0.6 & 0.8 & 0.117 & 0.345 \\
\hline $\begin{array}{l}\text { Advances In Intelligent } \\
\text { Systems and Computing }\end{array}$ & 41 & $1.06 \%$ & $\begin{array}{l}\text { Springer } \\
\text { Nature }\end{array}$ & 0.9 & $\mathrm{~N} / \mathrm{A}$ & $\mathrm{N} / \mathrm{A}$ & 0.428 \\
\hline
\end{tabular}




\subsubsection{Publication by Country}

The ten most productive countries in terms of publications are shown in Table 3. Four Asian countries, including Malaysia, are ranked in the top ten (247 publications). China tops the list with $422(10.89 \%)$ documents, followed by the United States with 358 (9.24\%) and the United Kingdom with 284 (7.33\%). China's dominance in publishing is not surprising, given the funding available to researchers, which results in papers that have frequently been cited with high research value, as well as with a consistent theme and clear direction of the research in areas, such as technical assistance, learning design, learning mode, and practices over the last decade (Zhang, 2020).

This finding is corroborated by Table 2, which lists the most frequently used source titles. For example, according to a further search of the Scopus database, a total of 112 articles for the proceedings have been contributed since 2003, and among the highest are Lecture Notes in Computer Science, including a sub-series of Lecture Notes in Artificial Intelligence and Lecture Notes in Bioinformatics. Between 2003 and 2020, this source contributed 72 articles.

During the study period, there were some countries, which produced less scholarly articles than others. Thus, this indicates an increase from three Asianbased institutions in the top ten countries in 2001 to 2010, to four Asian-based institutions in the top ten countries in 2011 to 2020. As a result, because mobile learning is linked inextricably to technological distribution, these developing countries, such as Taiwan, Malaysia, and Indonesia, can now be considered to have a relative technological advantage in education.

Table 3: Top 10 countries that contributed to the publications

\begin{tabular}{|l|c|c|c|c|c|c|c|}
\hline Country & TP & NCP & TC & C/P & C/CP & $\boldsymbol{h}$ & $g$ \\
\hline China & 422 & 241 & 1860 & 4.41 & 7.72 & 17 & 35 \\
\hline United States & 358 & 269 & 6564 & 18.34 & 24.40 & 43 & 74 \\
\hline United Kingdom & 284 & 229 & 6253 & 22.02 & 27.31 & 32 & 74 \\
\hline Taiwan & 282 & 225 & 7191 & 25.50 & 31.96 & 42 & 80 \\
\hline Malaysia & 247 & 169 & 1967 & 7.96 & 11.64 & 23 & 37 \\
\hline Indonesia & 184 & 101 & 392 & 2.13 & 3.88 & 10 & 13 \\
\hline Australia & 177 & 146 & 2412 & 13.63 & 16.52 & 23 & 44 \\
\hline Spain & 163 & 134 & 1741 & 10.68 & 12.99 & 20 & 37 \\
\hline Germany & 128 & 85 & 819 & 6.40 & 9.64 & 13 & 25 \\
\hline Canada & 107 & 82 & 1239 & 11.58 & 15.11 & 17 & 33 \\
\hline
\end{tabular}




\subsubsection{The Subject Area}

According to Table 4, the most frequently written subject in computer science during this period (2001-2020) was mobile learning (65.07\%). The data demonstrate a consistent pattern, since Goksu's (2021) most recent bibliometric analyses in 2019. Elaish et al. (2019), conducted a bibliometric analysis between 1982 and 2015; and they discovered that 150 out of 500 articles in the top five journals publishing articles on mobile learning originated in the field of computerscience research. A two-decade analysis from 2001-2020 found an unusual change, in which computer science now accounts for $65 \%$ of mobile learning publications, followed by social science $(47.5 \%)$, engineering $(21.09 \%)$, and mathematics $(8.01 \%)$.

This pattern demonstrates that mobile learning is gaining traction in computer science, as was previously evident in the literature. Increased research on educational tools, applications, approaches, design and development may account for computer-science research's predominance. This is due to the popularity of mobile devices, cell phones, smart-coaching systems and interactive learning environments that have been widely used in the past two decades (Goksu, 2021). Overall, this bibliometric analysis shows that computer science research seemed slow to recognise the advantages of mobile learning at the beginning of the millennium, thereby indicating the development of research applications.

Table 4: Subject area

\begin{tabular}{|l|c|c|}
\hline Subject Area & $\begin{array}{c}\text { Total Publications } \\
\text { (TP) }\end{array}$ & $\begin{array}{c}\text { Percentage } \\
\text { (\%) }\end{array}$ \\
\hline Computer Science & 2521 & 65.07 \\
\hline Social Sciences & 1840 & 47.50 \\
\hline Engineering & 817 & $21.09 \%$ \\
\hline Mathematics & 312 & $8.05 \%$ \\
\hline Business, Management and Accounting & 209 & $5.39 \%$ \\
\hline Arts and Humanities & 130 & $3.36 \%$ \\
\hline Decision Sciences & 129 & $3.33 \%$ \\
\hline Medicine & 96 & $2.48 \%$ \\
\hline Psychology & 89 & $2.30 \%$ \\
\hline Physics and Astronomy & 84 & $2.17 \%$ \\
\hline Economics, Econometrics and Finance & 58 & $1.50 \%$ \\
\hline Energy & 48 & $1.24 \%$ \\
\hline Materials Science & 47 & $1.21 \%$ \\
\hline
\end{tabular}




\begin{tabular}{|l|c|c|}
\hline Environmental Science & 41 & $1.06 \%$ \\
\hline Health Professions & 32 & $0.83 \%$ \\
\hline $\begin{array}{l}\text { Biochemistry, Genetics and Molecular } \\
\text { Biology }\end{array}$ & 19 & $0.49 \%$ \\
\hline Nursing & 15 & $0.39 \%$ \\
\hline Agricultural and Biological Sciences & 14 & $0.36 \%$ \\
\hline Chemistry & 14 & $0.36 \%$ \\
\hline Earth and Planetary Sciences & 12 & $0.31 \%$ \\
\hline Multidisciplinary & 12 & $0.31 \%$ \\
\hline Chemical Engineering & 11 & $0.28 \%$ \\
\hline $\begin{array}{l}\text { Pharmacology, Toxicology and } \\
\text { Pharmaceutics }\end{array}$ & 10 & $0.26 \%$ \\
\hline Immunology and Microbiology & 4 & $0.10 \%$ \\
\hline Neuroscience & 3874 & $0.10 \%$ \\
\hline Total & & 100.00 \\
\hline
\end{tabular}

\subsection{Patterns of Citations in Mobile Learning}

The purpose of RQ 2 is to ascertain the current citation pattern for the most influential publications on mobile learning in Scopus. Citation analysis is used to determine the impact of articles on mobile learning (Baker et al., 2020). Citation metrics for 3,874 articles obtained since approximately 4th May 2021, indicate an average of 1,978 . Ten citations per year are required, with 39,574 citations reported to address RQ2, as in Table 5.

Table 5: Citation metrics

\begin{tabular}{|l|c|}
\hline Metrics & Data \\
\hline Papers & 3874 \\
\hline Number of Citations & 39562 \\
\hline Years & 20 \\
\hline Citations per Year & 1978.10 \\
\hline Citations per Paper & 10.21 \\
\hline Cite_Authors & 18342.73 \\
\hline Paper_Authors & 1815.92 \\
\hline Authors'_Paper & 2.79 \\
\hline h_index & 87 \\
\hline g_index & 140 \\
\hline
\end{tabular}


(As illustrated in Figure 3, the most frequently cited source titles are conference proceedings and journals). A total of 61 source titles met these criteria, based on a minimum number of the source title's documents, of which the citations are equal to five.

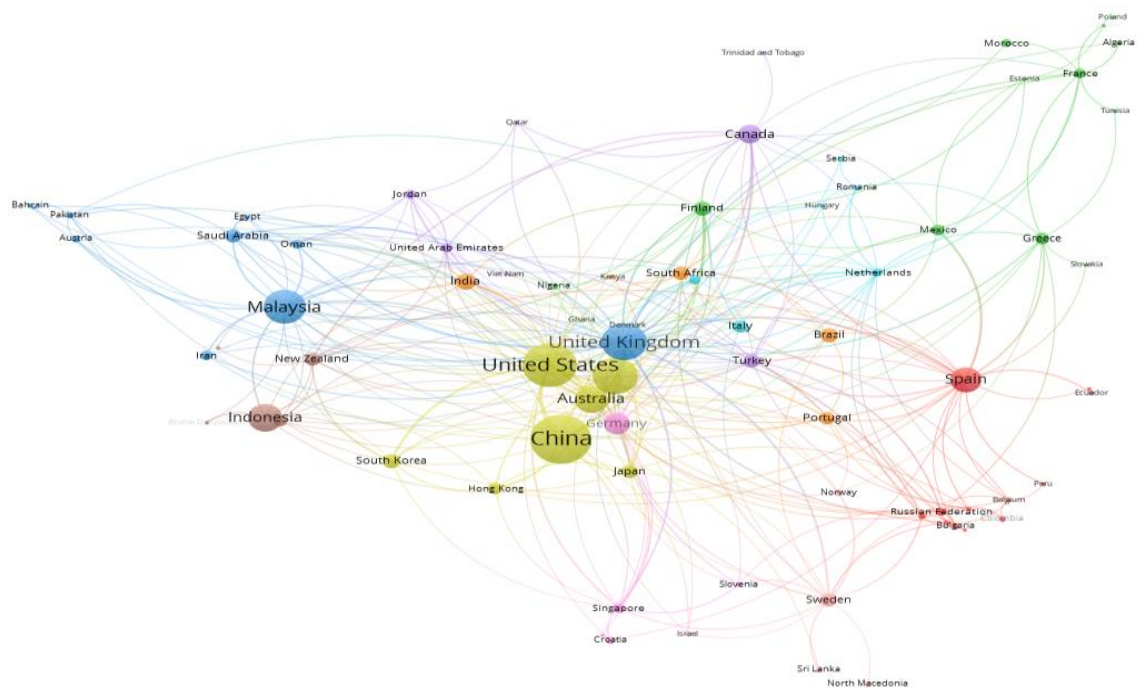

Figure 3: Visualisation of the citation network by country

Note: Minimum number of documents of an author $=5$; Minimum number of citations of an author $=5$

In addition to the data in Table 2, Figure 4 illustrates the most active source titles in mobile learning research, as measured by the number of documents produced. However, when the cite score of the most highly cited journal is examined, the following source titles (Table 2) rank in the top five: Computers and Education (14.4), British Journal of Educational Technology (7.6), Educational Technology and Society (7.2), International Review of Research in Open and Distance Learning (5.8), and Education and Information Technologies (5.8). (5.4).

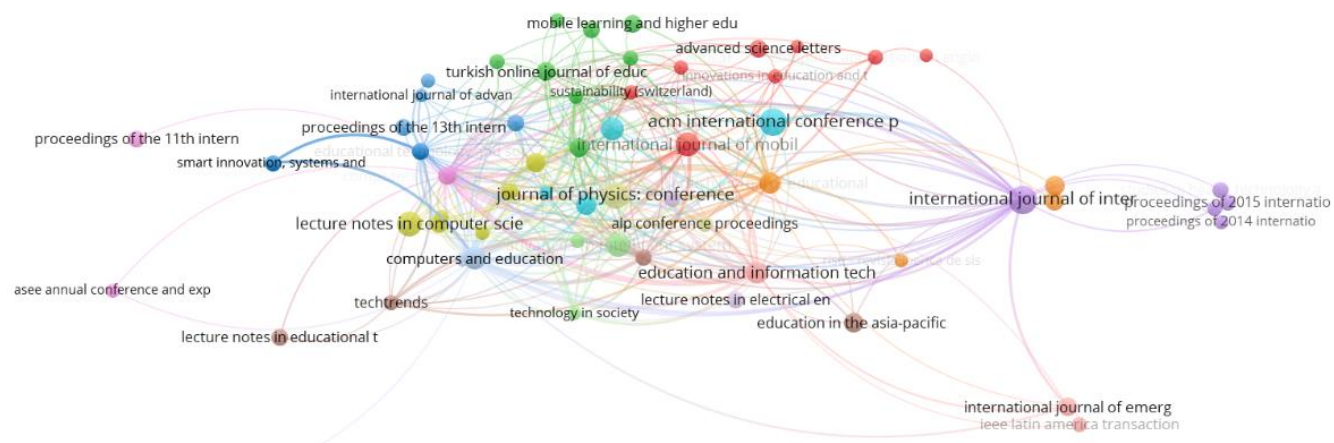

Figure 4: The citation by source network visualisation map 


\subsection{Themes in Research on Mobile Learning}

To answer the third research question, which mobile learning theme is most popular among scholars? analysis of the co-occurrence of keywords and terms in the title and abstract data extracted from the Scopus database was performed. Accordingly, for two keywords to appear in the same article, it indicates that the two concepts share a great deal of common ground (Baker et al., 2020). To ensure that the author's keywords accurately describe the content of the article, cooccurrence and keywords were used (Comerio \& Strozzi 2019).

\subsubsection{Author's Keywords}

Gonza'lez et al. (2018) assert that authors' keywords and their co-occurrence provide a complete picture of what occurs in a field of study. After removing duplicates caused by spelling differences, Table 6 shows the most popular author keywords during the first two decades of the millennium (e.g., m learning, mlearning). VOS-viewer was used in mapping all the keywords for each article, which included both author and index keywords, as illustrated in Figure 5. We examined the co-occurrence of each keyword that appears in this section at least five times. This threshold resulted in the discovery of 530 keywords. The strength of the relationship between the keywords is illustrated in Figure 5, which is represented by the size of the circle, the size of the font, the colour, and the thickness of the connecting line (Sweileh et al., 2017).

Table 6: Top used keywords

\begin{tabular}{|l|c|c|}
\hline Author Keywords & Total Publications (TP) & Percentage (\%) \\
\hline Mobile Learning & 2212 & $57.07 \%$ \\
\hline E-learning & 1624 & $41.90 \%$ \\
\hline Students & 737 & $19.01 \%$ \\
\hline Learning Systems & 711 & $18.34 \%$ \\
\hline M-Learning & 665 & $17.16 \%$ \\
\hline Education & 640 & $16.51 \%$ \\
\hline Mobile Devices & 623 & $16.07 \%$ \\
\hline M-learning & 540 & $13.93 \%$ \\
\hline Teaching & 491 & $12.67 \%$ \\
\hline Computer-Aided Instruction & 424 & $10.94 \%$ \\
\hline Engineering Education & 412 & $10.63 \%$ \\
\hline Mobile Technology & 282 & $7.28 \%$ \\
\hline Higher Education & 222 & $5.73 \%$ \\
\hline Surveys & 190 & $4.90 \%$ \\
\hline Mobile-learning System & 189 & $4.88 \%$ \\
\hline Mobile Telecommunication & 176 & $4.54 \%$ \\
\hline Education Computing & 175 & $4.51 \%$ \\
\hline Telecommunication Equipment & 175 & $4.51 \%$ \\
\hline
\end{tabular}




\begin{tabular}{|l|l|l|}
\hline Curricula & 173 & $4.46 \%$ \\
\hline Mobile Applications & 171 & $4.41 \%$ \\
\hline
\end{tabular}

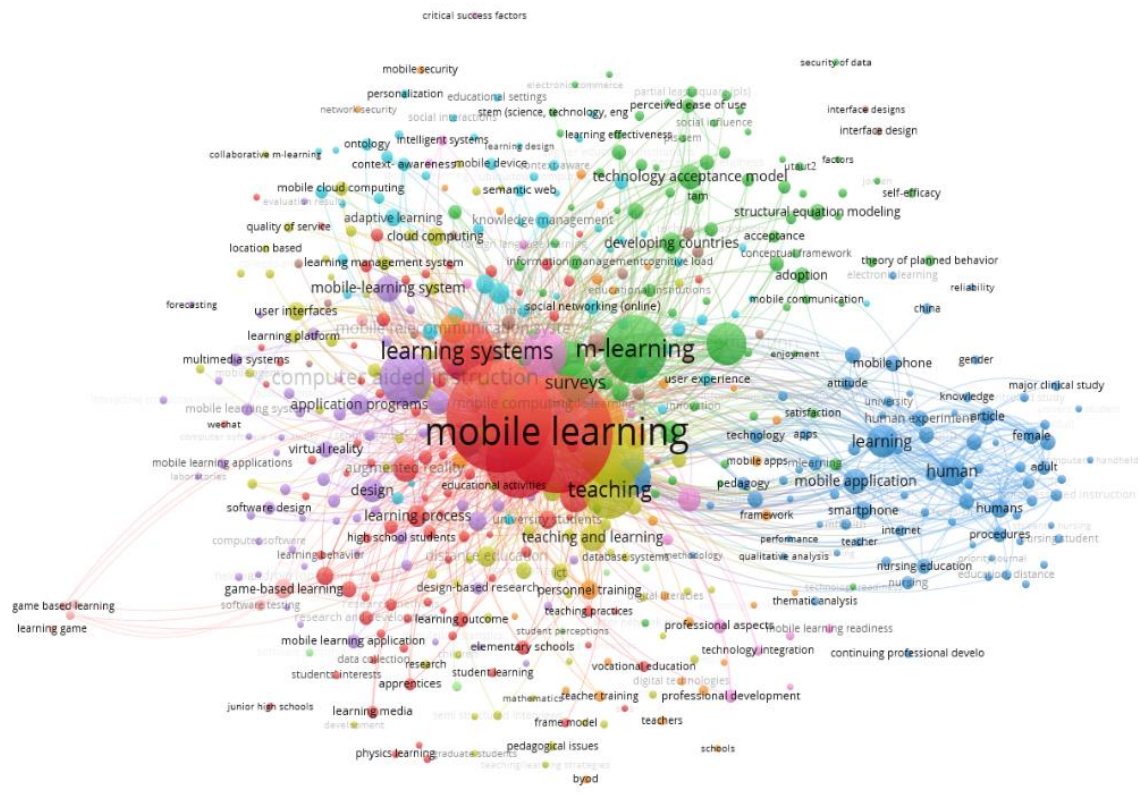

Figure 5: Network visualisation map of all the keywords

As illustrated in Figure 5, the terms mobile learning, learning system, augmented reality, surveys, learning outcomes, learning process and game-based learning are frequently used interchangeably; since they are closely related, and frequently occur in conjunction with each other. A different colour represents each of the eleven clusters identified in this visualisation map in this figure. Six clusters contain a top cluster containing at least 50 items. The top three clusters contain 87 items (red) on mobile learning, 83 items (green) on m-learning, and 80 items (blue) on human learning. This cluster demonstrates that human studies of mobile learning and m-learning have been conducted, particularly in computer science. This map is also demonstrated by three additional clusters, demonstrating that this field also focuses on education, a teaching aid. That is, 72 educational items (yellow-green), 61 computer-aided instruction items (purple), and 58 computeraided instruction items (sky blue).

\subsubsection{Title and Abstract}

This study examined the phrase co-occurrence network using the title and abstract fields. In this configuration, 61 words met the threshold. However, a relevance score was generated for each of the 61 terms, choosing the most acceptable score. The $60 \%$ most acceptable terms have been chosen by using the default setting. As a result, the number of terms chosen was 3,502, the VOS-viewer software's default value, as illustrated in Figure 6. This visualisation map resulted in the creation of a map of these terms' co-occurrences. The distance between nodes represents the relationship between phrases or concepts in this network visualisation, whereas the nodes themselves represent the terms or concepts (Sedighi,2016). Each colour in this illustration represents a different phase. As a result, the map will contain 
six clusters representing six distinct themes. This map depicts six themes: (red) elearning (55 items), (green) mobile learning (28 items), (blue) education (26 items), (yellow/green) students (26 items), (purple) information and communication (16 items), and (sky-blue) teaching group (14 items).

This cluster demonstrates that the theme of writing in mobile learning is focused on education, which incorporates e-learning into its teaching and learning processes.

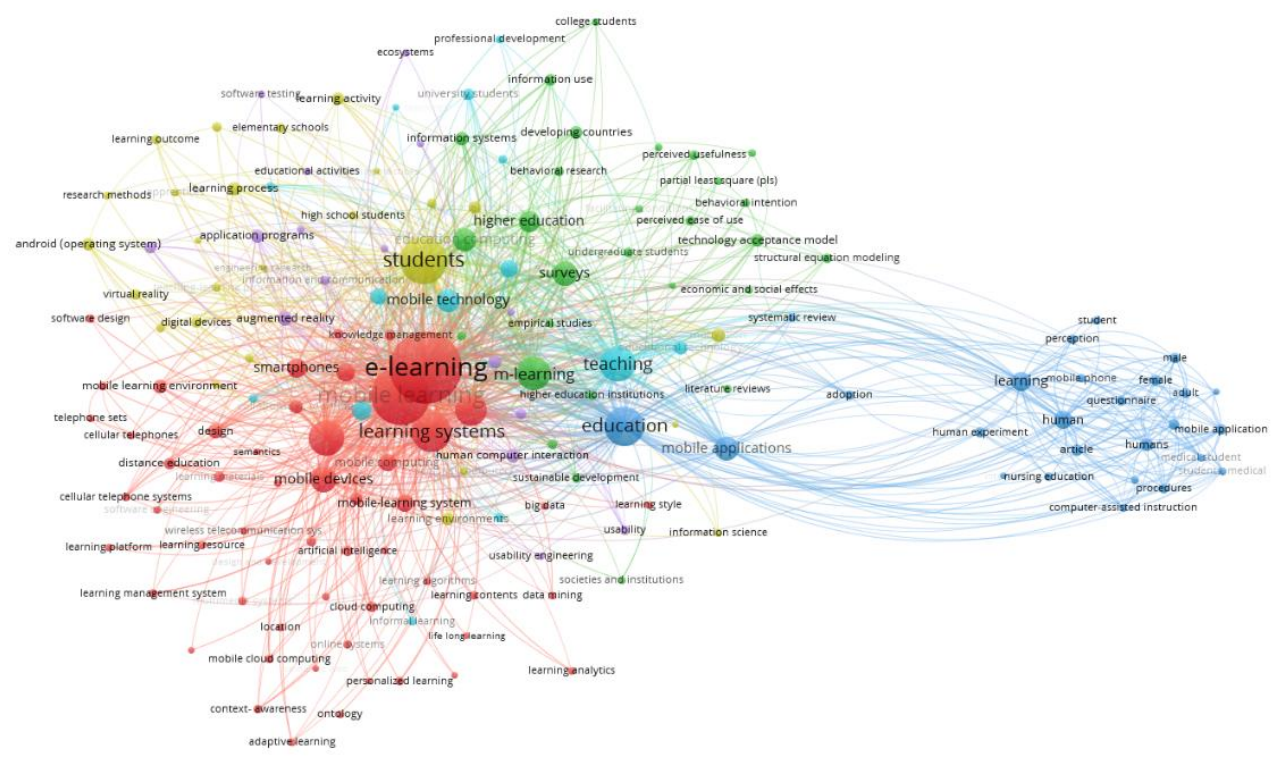

Figure 6: Network visualisation using the title and abstract field of a phrase cooccurrence in VOS-viewer (Full Counting)

\section{Discussion}

This section elaborates on prior findings by responding to the research questions.

RQ1: What has been the recent trend in mobile learning publications?

This bibliometric analysis of publications published between 2001 and early 2020 is timely; because it quantifies the extent to which the trend towards mobilelearning applications has persisted over the first two decades of the twenty-first century; and it will probably continue into the next two decades. The pattern of publication of mobile-learning strategies/approaches that go up and down, according to the current situation, will continue to attract more practitioners, researchers and scholars in the coming decade, in which the use of mobile learning will surely continue. Moreover, the analysis shows a high level of involvement by developing countries, especially Asian countries, in this type of research.

Guksu (2021) discovered that Asian countries were the most active in mobilelearning research between 2015 and 2019. As this study demonstrates, the results of two decades of research from developing countries run consistently with justifiable gaps; and they indicate the improvement of educational technology in these developing countries since the beginning of the millennium. 
According to the tables and data in the preceeding sections, mobile learning appears likely to be widespread in the future. The advancement of technologybased education has proven to be an excellent option, especially at difficult times when synchronous learning with face-to-face physical teaching and learning sessions are unavailable, or considered to be impractical. Hence, it increases security by customising digital educational materials, based on the student's learning style and the device's requirements (Vallejo-Correa et al., 2021). This has implications for researchers in the field of education to ensure that the use of mobile learning is a necessity for online learning where most students are more into the use of the mobile devices, and the learning styles are more into audio, visual, and hands-on, which is video.

Indeed, the current COVID-19 epidemic, for example, has prompted worldwide requests for emergency remote teaching and learning instruction. Therefore, educators need to sharpen their competencies and expand their understanding of mobile learning and its integration into the process of incorporating technology into their educational methods for today's digital natives (Rajendran \& Yunus, 2021).

RQ2: What is the current citation pattern for mobile learning publications?

To date, 39,562 citations have been obtained from 3,874 documents, representing a total of 1,978.10 citations per year, 10.21 citations per paper, 1,815.92 papers per author, and 2.79 authors per paper. In addition, only 1,213 out of 3,874 documents have been cited so far. Mobile-learning studies have also achieved a $47 \mathrm{~h}$-index and 140 g-index at the time when these data were analysed. This analysis guides journal publishers to see whether publications in the Scopus database provide many citations to authors. Moreover, this analysis also provides a guideline that the publication of articles has a high allocation for acquisitional budgetbreakdown (Bowman, 1991).

Publishers need to ensure that published articles cite those articles that have been published by the journal, so that the number of citations would increase on the Scopus-database platform.

RQ3: Which mobile learning topics are most popular among scholars?

Based on the analysis of all the keywords, this study identified eleven themes, including mobile learning, m-learning, human, education, computer-assisted instructions, human interaction, mobile-technology interactions, intelligencesystem games, and engagement. Nevertheless, this visualisation map contains six clusters, based on terms occurrences in the title and abstract of Scopus articles. These themes were classified as follows: e-learning was assigned as theme one; m-learning was assigned as theme two; education was assigned as theme three; students were assigned as theme four, information and communication were assigned as theme five, and teaching was assigned as theme six. Consequently, these issues appear to be central in mobile-learning research. 
RQ4: What areas of mobile learning require additional research?

As stated in the previous sections, at the turn of the second millennium, the global use of mobile phones increased, due to the COVID-19 pandemic, which resulted in the Movement Control Order (MCO). This MCO will profoundly affect the education systems in developing countries, and the least developed and emerging countries, in which most teaching and learning occur online (Hofer et al., 2021). Most teaching materials are uploaded online and implemented by using blended learning, flipped learning, and online-learning methods. There are no issues with internet connectivity, bandwidth, or ICT equipment in most developing and highincome countries.

However, students in the least developed low-income countries typically only have access to a telecommunication device, such as a mobile phone, which relies on mobile data to assist those with limited internet capacity. The use of social media and apps, such as Facebook, Instagram, Twitter, WhatsApp, WeChat, telegram, and game-based learning apps has enabled students to self-regulate their learning by uploading learning materials to an online platform by using their own, or their parents', mobile device, thereby enabling teachers to teach remotely from home via asynchronous learning by using videos.

However, because mobile learning focuses on the device, apps, and learning approach, there is concern about how interactions, engagement, motivation and critical thinking occur during online synchronous and asynchronous learning (Har et al., 2019; Thomas, 2020; Al-Shamsi et al., 2020). As a result of this concern, various instructional designs have emerged that are appropriate for the device, apps, and for the learning approach used. For instance, how to create lesson plans appropriate for online synchronous and asynchronous learning via mobile devices, apps and platforms. The future study will concentrate on the use of mobile applications by most students, who only have access to a mobile phone and mobile data, when they are learning online.

The lesson-plan design and mobile-application development of these teaching materials should consider students' interaction and engagement with teachers and teaching materials (Purarjomandlangrudi \& Chen, 2020). This situation demonstrates the critical need for continuous professional development programmes, to which all educators must adhere, in order to ensure that all students receive an adequate education during this critical period (Lowenthal, 2020). The end of the pandemic is unknown. Beyond the existing applications, there is still considerable room for growth in game-based learning, learning algorithms, learning technologies, software prototyping, interface design, data security, online coaching, online facilitation, and online feedback. By identifying and exploring these approaches, this argument implies that diversifying mobile learning approaches are a real possibility.

\section{Conclusion}

The purpose of this study was to examine the pattern of mobile-learning research, the pattern of citations, and the visualisation of the theme, and to make 
recommendations for future research directions in mobile learning. The data were gathered via keyword searches for "m-learning" and "mobile learning" with the data extracted directly beneath the "title of the article". Additional research in other areas, such as "abstracts and keywords", should be conducted, which will require further screening and filtering of the dataset. As a result, the teachers and educators identified can change pedagogy, in order to cope with the evolution of educational technology that uses mobile-learning applications.

The findings of this study will assist academics in gaining a better understanding of the global impact of mobile learning. Mobile learning is expected to continue to gain popularity over the next few decades, because of the online-learning applications that have increased students' engagement and closed the accessibility gap. This popularity demonstrates the critical role of online learning. Furthermore, in addition to technological advancements that have accelerated many people's adoption of mobile learning, the rise of an electronic-data security threat, due to electronic accessibility, has actively contributed to many instructors and students being placed in dangerous situations.

For example, the use of mobile-learning approaches and cyber threats in various domains of education highlights the risk associated with the collection of students' and educators' data over time. When users signed up for specific applications for web-based online learning resources and completed their profiles on a digital platform, they exposed themselves to cyber risk. As a result, it is a subject that requires additional attention from scholars and practitioners involved in developing lessons and mobile-learning applications. Thus, this new line of research should result in a more-advanced visualisation of mobile-learning patterns in the coming decade.

\section{References}

Abernathy, D. J. (2001). Get ready for M-learning. T and D, 55(2), 20.

Akour, I., Alshurideh, M., Al Kurdi, B., Al Ali, A., \& Salloum, S. (2021). Using machinelearning algorithms to predict people's intention to use mobile learning platforms during the COVID-19 pandemic: Machine learning approach. JMIR Medical Education, 7(1), 1-17. https:// doi.org/10.2196/24032

Ahmi, A., \& Mohamad, R. (2019). Bibliometric analysis of global scientific literature on web accessibility. International Journal of Recent Technology and Engineering, 7(6), 250-258.

Ahmi, A., \& Mohd Nasir, M. H. (2019). Examining the trend of the research on extensible business reporting language (XBRL): A bibliometric review. International Journal of Innovation, Creativity and Change, 5(2), 1145-1167. https:// ssrn.com/abstract $=3839843$

Al-Shamsi, A., Abdo Mohamed Al-Mekhlafi, A. M., Busaidi, S. A., \& Hilal, M. M. (2020). The effects of mobile learning on listening comprehension skills and attitudes of Omani EFL adult learners. International Journal of Learning, Teaching and Educational Research, 19(8), 16-39. https://doi.org/10.26803/ijlter.19.8.2

Attewell, J., \& Gustafsson, M. (2002). Mobile communications technologies for young adult learning and skills development (m-learning) [Paper presentation]. IEEE International Workshop on Wireless and Mobile Technologies in Education, WMTE 2002, 158160. https://doi.org/10.1109/WMTE.2002.1039240 
Baker, H. K., Pandey, N., Kumar, S., \& Haldar, A. (2020). A bibliometric analysis of broad diversity: Current status, development, and future research directions. Journal of Business Research, 108, 232-246. https:// doi.org/10.1016/j.jbusres.2019.11.025

Barrett, N. E., Liu, G. Z., \& Wang, H. C. (2021). Student perceptions of a mobile learning application for English Oral Presentations: the case of EOPA. Computer Assisted Language Learning, 0(0), 1-26. https:/ / doi.org/10.1080/09588221.2021.1881975

Bowman, M. (1991). Format citation patterns and their implications for collection development in research libraries. Collection Building, 11(1), 2-8. https://doi.org/10.1108/eb023290

Burnham, J. F. (2006). Scopus database: A review. Biomedical digital libraries, 3(1), 1. https://doi.org/10. 1186/1742-5581-3-1

Cantu-Ortiz, F. J. (Ed.). (2017). Research Analytics: Boosting University Productivity and Competitiveness through Scientometrics (1st ed.). Auerbach Publications. https://doi.org/10.1201/9781315155890

Criollo-C, S., Guerrero-Arias, A., Jaramillo-Alcázar, Á., \& Luján-Mora, S. (2021). Mobile learning technologies for education: Benefits and pending issues. Applied Sciences, 11(9). https://doi.org/10.3390/app11094111

Criollo-C, S., Moscoso-Zea, O., Guerrero-Arias, A., Jaramillo-Alcazar, A., \& Lujan-Mora, S. (2021). Mobile Learning as the key to higher education innovation: A systematic mapping. IEEE Access, 9, 66462-66476. https://doi.org/10.1109/ACCESS.2021.3076148

Díaz-Sainz, G., Pérez, G., Gómez-Coma, L., Ortiz-Martínez, V. M., Domínguez-Ramos, A., Ibañez, R., \& Rivero, M. J. (2021). Mobile learning in chemical engineering: An outlook based on case studies. Education for Chemical Engineers, 35, 132-145. https://doi.org/10.1016/j.ece.2021.01.013

Ding, X., \& Yang, Z. (2020). Knowledge mapping of platform research: a visual analysis using VOS-viewer and Cite Space. Electronic Commerce Research. https:// doi.org/10.1007/s10660-020-09410-7

Donthu, N., Kumar, S., Mukherjee, D., Pandey, N., \& Lim, W. M. (2021). How to conduct a bibliometric analysis: An overview and guidelines. Journal of Business Research, 133, 285-296. https:/ / doi.org/10.1016/j.jbusres.2021.04.070

Elaish, M. M., Shuib, L., Ghani, N. A., Mujtaba, G., \& Ebrahim, N. A. (2019). A bibliometric analysis of m-learning from topic inception to 2015. International Journal of Mobile Learning and Organisation, 13(1), 91. https:/ / doi.org/10.1504/ijmlo.2019.096470

Goksu, I. (2021). Bibliometric mapping of mobile learning. Telematics and Informatics, 56, 101491. https:/ / doi.org/10.1016/j.tele.2020.101491

Gonza'lez, L. M., Garcı'a, M. X., Pardolbañez, A., Peset F., Devı's, D. J. (2018). An author keyword analysis for mapping Sport Sciences. PLoS ONE 13(8): e0201435. https://doi.org/ 10.1371/journal.pone.0201435

Har, A. L.C., Mohamad, J. Z. A., \& Jamal, S. S. (2019). The benefits and drawbacks of using tablet-based digital storytelling in vocabulary learning among Malaysian young English as a Second Language (ESL) learners. Asia Pacific Journal of Educators and Education, 34, 17-47. https://doi.org/10.21315/apjee2019.34.2

Hitchcock, S. (2004). The effect of open access and downloads ('hits') on citation impact: A bibliography of studies. Southampton, GB. University of Southampton. http:/ / eprints.soton.ac.uk/id/eprint/354006

Hofer, S. I., Nistor, N., \& Scheibenzuber, C. (2021). Online teaching and learning in higher education: Lessons learned in crisis situations. Computers in Human Behavior, 121. https://doi.org/10.1016/j.chb.2021.106789

Houser, C., Thornton, P., \& Kluge, D. (2002). Mobile learning: Cell phones and PDAs for education [Paper presentation]. International Conference on Computers in Education, ICCE 2002, 1149-1150. https:/ / doi.org/10.1109/CIE.2002.1186176 
Huang, R. T., Yu, C. L., Tang, T. W., \& Chang, S. C. (2021). A study of the use of mobile learning technology in Taiwan for language learning. Innovations in Education and Teaching International, 58(1), 59-71. https:// doi.org/10.1080/14703297.2019.1628798

Ichinohe, A., \& Suzuki, K. (2002). Expansion of the i-mode drill "the world of kanji" with review functions for m-learning. Paper presented at the Proceedings - International Conference on Computers in Education, ICCE 2002, 1472-1473. https://doi.org/10.1109/CIE.2002.1186302

Lowenthal, P., Borup, J., West, R., \& Archambault, L. (2020). Thinking beyond Zoom: using asynchronous video to maintain connection and engagement during the COVID-19 pandemic. Journal of Technology and Teacher Education, 28(2), 383-391. https:// www.learntechlib.org/primary/p/216192/

Lo, C., Ng, K., \& Lu, Q. (2002). CJK knowledge management in multi-agent M-learning system [Paper presentation]. International Conference on Machine Learning and Cybernetics, 4 1983-1986. https:/ / doi.org/10.1109/ICMLC.2002.1175384

Mifsud, O. (2002). Alternative learning arenas-pedagogical challenges to mobile learning technology in education [Paper presentation]. IEEE International Workshop on Wireless and Mobile Technologies in Education, WMTE 2002, 112-116. https:// doi.org/10.1109/WMTE.2002.1039231

Moher, D., Liberati, A., Tetzlaff, J., \& Altman, D. G., (2009). Preferred reporting items for systematic reviews and meta-analyses: The PRISMA Statement. PLoS Med 6(7), e1000097. https://doi.org/10.1371/journal.pmed1000097

Moya, S., \& Camacho, M. (2021). Identifying the key success factors for the adoption of mobile learning. Education and Information Technologies, 26(2), 1-29. https:// doi.org/10.1007/s10639-021-10447-w

Mutiaraningrum, I., \& Nugroho, A. (2021). Smartphone-based mobile assisted language learning application in higher vocational education in Indonesia. Journal of English Educators Society, 6(1). https://doi.org/10.21070/jees.v6i1.793

Nurul Azni, M. A., \& Nailul Murad, M. N. (2018). Potential usage of mobile learning via Short Messaging System (SMS) for enhancing Islamic knowledge of adult learners. Asia Pacific Journal of Educators and Education, 33, 29-46. https:// doi.org/10.21315/apjee2018.33.3

Nyiri, K. (2002). Towards a philosophy of m-learning. [Paper presentation]. IEEE International Workshop on Wireless and Mobile Technologies in Education, WMTE 2002, 121124. https://doi.org/10.1109/WMTE.2002.1039233

Prillya, C. R., Gani, S. A., \& Marhaban, S. (2021). An investigation of media Ruangguru as educational online platform in studying English. English Education Journal, 12(1), 89-103. https://doi.org/10.24815/eej.v12i1.17440

Purarjomandlangrudi, A., \& Chen, D. (2020). Exploring the influence of learners' personal traits and perceived course characteristics on online interaction and engagement. Education Technology Research and Development, 68(5), 2635-2657. https://doi.org/10.1007/s11423-020-09792-3

Rajendran, T. \& Yunus, M. M. (2021). Chatterpix Kids: A potential mobile app for helping primary ESL pupils to improve their speaking fluency. International Journal of Learning, Teaching and Educational Research, 20(4), 18-42. https://doi.org/10.26803/ijlter.20.4.2

Sedighi, M. (2016). Application of word co-occurrence analysis method in mapping of the scientific fields case study: The field of Informetrics. Library Review, 65(1/2), 52 64. https://doi.org/10.1108/lr-07- 2015-0075

Seppälä, P., \& Alamäki, H. (2002). Mobile learning and mobility in teacher training [Paper presentation]. IEEE International Workshop on Wireless and Mobile Technologies in Education, WMTE 2002, 130-135. https:/ / doi:10.1109/WMTE.2002.1039235 
Seppälä, P., Sariola, J., \& Kynäslahti, H. (2002). Mobile learning in personnel training of university teachers [Paper presentation]. IEEE International Workshop on Wireless and Mobile Technologies in Education, WMTE 2002, 136-139. https:// doi.org/10.1109/WMTE.2002.1039236

Sharples, M., Corlett, D., \& Westmancott, O. (2002). The design and implementation of a mobile learning resource. Personal Ubiquitous Computing, 6, 220-234. https://doi.org/10.1007/s007790200021

Shi, Y., Blainey, S., Sun, C., \& Jing, P. (2020). A literature review on accessibility using bibliometric analysis techniques. Journal of Transport Geography, 87. https://doi.org/10.1016/j.jtrangeo.2020.102810

Sungur-gul, K., \& Ates, H. (2021). Turkish adaptation of mobile learning readiness scale in the framework of theory of planned. International Online Journal of Education and Teaching, 8(2), 814-831. https:// www.iojet.org/index.php/IOJET/article/view/1114

Sweileh, W. M., Al-Jabi, S. W., AbuTaha, A. S., Zyoud, S. H., Anayah, F. M. A., \& Sawalha, A. F. (2017). Bibliometric analysis of worldwide scientific literature in mobile health: 2006-2016. BMC Medical Informatics and Decision Making, 17(1), 72. https://doi.org/10.1186/s12911-017-0476-7

Thomas, D. (2020). Social media addiction, critical thinking and achievement emotions among efl students in Thailand. Asia Pacific Journal of Educators and Education, 35(1), 157-171. https://doi.org/10.21315/apjee2020.35.1.9

Uther, M. (2002). Mobile internet usability: What can 'mobile learning' learn from the past? [Paper presentation]. IEEE International Workshop on Wireless and Mobile Technologies in Education, WMTE 2002, 174-176. https://doi.org/10.1109/WMTE.2002.1039247

Vallejo-Correa, P., Monsalve-Pulido, J., \& Tabares-Betancur, M. (2021). A systematic mapping review of context-aware analysis and its approach to mobile learning and ubiquitous learning processes. Computer Science Review, 39. https:// doi.org/10.1016/j.cosrev.2020.100335

Van Eck, N. J., \& Waltman, L. (2020). VOS-viewer Manual. version 1.6.15. Leiden: University of Leiden. https://www.vosviewer.com/documentation/Manual_VOSviewer_1.6.10.pdf

Viberg, O., Andersson, A., \& Wiklund, M. (2021). Designing for sustainable mobile learning - re-evaluating the concepts "formal" and "informal". Interactive Learning Environments, 29(1), 130-141. https:// doi.org/10.1080/10494820.2018.1548488

Wang, Y., Wu, M., \& Wang, H. (2009). Investigating the determinants and age and gender differences in the acceptance of mobile learning. British Journal of Educational Technology, 40(1), 92-118. https:// doi.org/10.1111/j.1467-8535.2007.00809.x

Yuan, Y-P., Tan, G. W-H, Ooi, K-B., \& Lim, W-L. (2021). Can COVID-19 pandemic influence experience response in mobile learning?. Telematics and Informatics, 64. https://doi.org/10.1016/j.tele.2021.101676

Zhang, W. (2020). The research on the theme and development trend of mobile learning in China in the past ten years. Journal of Physics: Conference Series, Bristol, 1453. https://doi.org/10.1088/1742-6596/1453/1/012133 